\title{
THE INTERNATIONAL COMPETITIVENESS RANKS \\ OF GEORGIA AND COUNTRY'S FEATURES
}

\author{
M. Kavadze ${ }^{1}$ \\ DOI: http://doi.org/10.15350/L_26/8/10
}

\begin{abstract}
The paper deals with two important issues for Georgia: first, international competitiveness, and second, the impact of competitiveness on economic integration and vice versa. The European integration process has intensified the problem of competitiveness of the national economy by the following: first, by the reduction of protection measures, and second, by the liberalization of regional trade. It has been a good way to upgrade and strengthen competitiveness of the national economy. Regional economic integration is a supporting means for a gradual increase of competitiveness of a small open economy in transition. Full membership in the European Union involves strong competitive pressure on new member countries, on one hand, and a certain degree of collective protection, on the other.
\end{abstract}

Keywords: European Union, competitiveness, productivity.

The issue of international competitiveness of the national economy and its improvement has presented a part of development policies for decades. It has been intensified on international level by multilateral trade liberalization, steady growth of international trade, acceleration of technical progress, and by the progress of new industrialized countries.

The intensification of international competition should increase its importance. The international competitiveness can be defined as "a country's capability for most rational use of resources in accord to the international specialization and trade in such way that results, as a final goal, in growth of living standard and domestic product (so that growth should be founded on real basis but not on external indebtedness). A competitiveness comprises the capability for achieving high level of productivity on national level, upgrading of human capital, effective use of capital and other factors of production" [1, p.199]. Theoretically, a concept of competitiveness is usually linked to the theory of comparative advantage, from early models to new ones. However, the former theories could not explain new phenomena and patterns in international trade and new theories have been developed. Depending on a region or country, an importance of individual factors of production has been also changed. At the beginning of 1990s, Michael Porter (1990) has explained new view related on competitiveness of the national economy emphasizing the productivity as the

${ }^{1}$ Miranda Kavadze, Doctoral Student of Economy Faculty, Kutaisi University, Georgia. 
most important factor. Some times before and after that, a number of models for measurement of individual elements of competitiveness have been developed.

Simultaneously with the spreading of globalization of world economy, the regionalism has intensified, and the solution was found in WTO rules: that regional economic integrations are not in colision with multilateral trade liberalization if they are established in accord with WTO rules. Obviously, the international legislation has been harmonized with practice. If we remember that every integration is basicaly preferential trade agreement, which by definition and in certain degree discriminates third countries, it suggests that integrations: first, mean certain distortion of free international market; and second, in that way modify the conditions of competition in an internal market. In such way, two groups of forces affect a competitiveness development in integrated market: the firsf one has a protective nature related to the foreign competitors, and the second one has the stimulative nature by spreading internal market. The character of their effect depends on the level of protectionism, and common policy of protection and competitiveness upgrading in an internal market.

Swiss organization - World Economic Forum (WEF) works on the issue of global competitiveness among the countries. Since 1979, that organization has been publishing an annual report, which offers the analysis of competitiveness and business environment of the countries. Every year, the organization makes a ranking, which depicts the Countries' positions in the world in terms of competitiveness. Each report is prepared on the basis of indicators of the past year. For instance, 2016-2017 report is based on 2015 assessment. The methodology of this organization employs 119 criteria to assess each country. Part of those criteria is based on official statistical information provided by the Government of Georgia. For criteria such as independence of judiciary, criminal and education level, the source of information is surveying the small, medium and large enterprises. Approximately 200 enterprises from Georgia participate in the survey.

World Economic Forum published 2016-2017 Global Competitiveness Report in September this year. Competitiveness of 139 countries is studied in the report. According to the new report, Georgia is $59^{\text {th }}$ position indeed, whilst last year it was at $66^{\text {th }}$ place.

If we take a look at the criteria (Table 1) employed by the index, Georgia has the best position ( $40^{\text {th }}$ place) in terms of macroeconomic environment. We hold $43-44^{\text {th }}$ places in terms of institutional development and labour market efficiency. Georgia has the worst position in terms of innovations $\left(116^{\text {th }}\right.$ place) and business sophistication (102 ${ }^{\text {nd }}$ place $)$.

We also studied what were the significant changes in the components of the index which affected Georgia's ranking. Points for property right protection increased from 4.3 to 4.4 which caused Georgia's progress from 58 th to $43^{\text {rd }}$ place. In terms of investors' protection, country's position got improved by 22 place. Amongst the macroeconomic criteria, significant improvement were registered in budget deficit (21 positions) and total national savings (38 position) components. Georgia's position in terms of loan affordability got 
improved by 57 position. Additionally, from $121^{\text {st }}$ place we moved to $105^{\text {th }}$ place in terms of innovation opportunities.

Table 1

Positions of Georgia in terms of Criteria

\begin{tabular}{|c|c|c|}
\hline Criteria according to groups & $\begin{array}{c}\text { Position in the } \\
\text { World }\end{array}$ & Points (maximum 7) \\
\hline Basic Demands & $\mathbf{4 6}$ & $\mathbf{4 . 9}$ \\
\hline Institutions & 43 & 4.4 \\
\hline Infrastructure & 65 & 4.1 \\
\hline Macroeconomic environment & 40 & 5.2 \\
\hline Health and primary education & 64 & 5.9 \\
\hline Incentives for Efficiency & $\mathbf{6 9}$ & $\mathbf{4 . 1}$ \\
\hline Higher Education and training & 89 & 4.1 \\
\hline Goods market efficiency & 46 & 4.6 \\
\hline Labour Market efficiency & 43 & 4.5 \\
\hline Financial market development & 58 & 4.2 \\
\hline Technological readiness & 65 & 4.2 \\
\hline Market Size & 101 & 3.0 \\
\hline Innovations and Sophistication factors & $\mathbf{1 1 3}$ & 3.2 \\
\hline Business sophistication & 102 & 2.8 \\
\hline Innovations & 116 & \\
\hline
\end{tabular}

Georgia's performance in some of the criteria, however, got significantly worse. The country moved down from $56^{\text {th }}$ to $63^{\text {rd }}$ place in terms of independence of judiciary. From $31^{\text {st }}$ we were downgraded to $43^{\text {rd }}$ place in terms of transparency of the policy of government. Indicators related to criminal also got worsened: business costs of crime and violence, organized crime and trust toward the police. Georgia moved from $28^{\text {th }}$ to $40^{\text {th }}$ position in terms of trust toward the police. In terms of quality of infrastructure Georgia moved 14 positions downward. Georgia moved 27 positions below in terms of inflation as well. State debt indicator got worsened too [2, p., 112].

According to the 2016-2017 Global Competitiveness Report, Georgia's ranking has indeed been improved by seven positions and stands now at $59^{\text {th }}$ position. The improvement was a result of positive changes in the following criteria: property rights, investors' protection, macroeconomic environment, loan affordability and innovation opportunities. In some, important criteria, however, Georgia's performance got worsened: independence of judiciary, transparency of the government's policy, criminal and trust toward the police, quality of infrastructure, inflation and state debt.

The increase flow of foreign capital stock, takes main place in determining of the economic globalization level which is an important part in showing of Economic development potential.

As a result of the reforms carried out in the years 2004-2007, the rapid rise of globalization index of Georgia begins since 2006. In the mentiond years 
was laid the foundation of today's business environment, who endured the war, economic crisis, political crisis and, in fact, non-stop Russian aggression. Against this background, it's paradox, how can develop Georgian's economy, who's increase, though in recent years (2014-2017) has slowed, but still achieves an average of $4 \%$ mark. (Table 2 ).

Table 2

The position of Geotgia in the economic globalization index

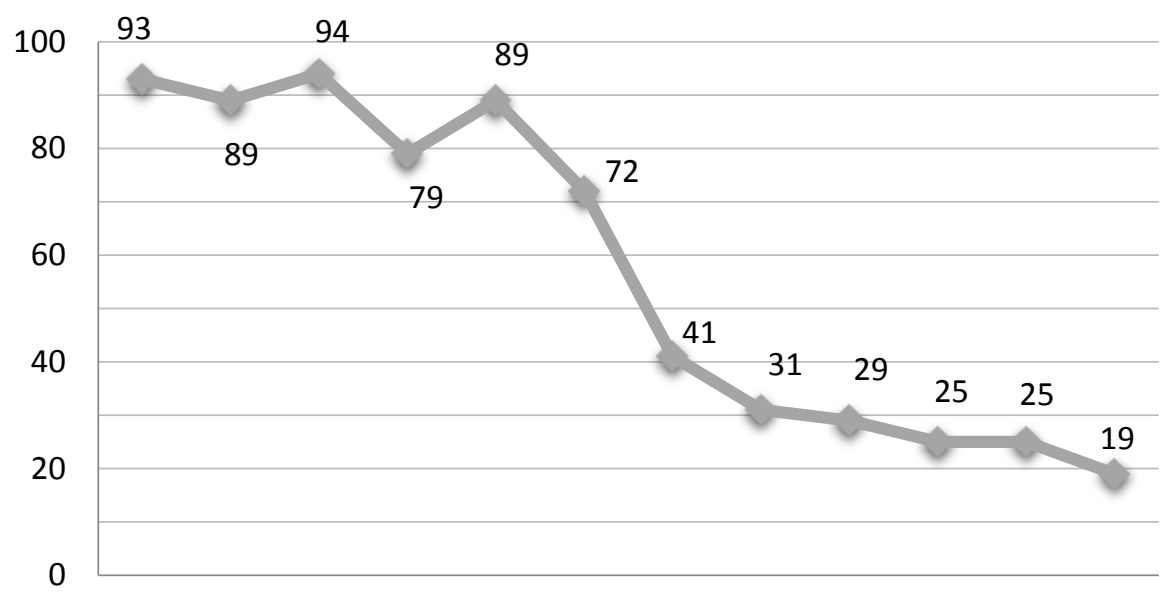

200620072008200920102011201220132014201520162017

The high level of globalization means that the economy of Georgia is not just 70 thousand square kilometers of locked land and 4.5 million human activities are limited, it means that Georgia has lots of ability for development [3.].

In the economic globalization $19^{\text {th }}$ place reflects the high level of economic freedom of Georgia, the economic development is the source of that inertia, which Georgia has since 2010 and which gradually decreases. It is necessary to carry out new reforms and to correct deficiencies. Attempts of entry delay of foreign goods, capital and labor force will end badly for Georgia.

According to the report of "Global Competitiveness Index", it becomes clear needs of in-depth economic reforms. The conducted liberalization has given us some positive results, however, further improvement in this direction is practically not bring any breakthrough. In order to increase investments in the country, development of infrastructure should be a priority for Georgia. The main components of infrastructure should be - the protection and development of human capital for more investment in health and education.

It is a major factor in the convergence of business and science issue. Unfortunately, as the world practice shows, quick and unilateral solutions do not work and must be implemented well-thought-out strategy.

Also it is important for Georgia to have predictable stability. Without the long-term stability foreign investment and the accompanying positive effects 
ecann't be available for Georgia. It is important for the development of modern economic and political institutions.

The realization of these proposals, we believe, will contribute to the improvement of competitiveness and the overall prosperity and elevated.

References

[1] Dollar D., Wolf E. The Global Competitive // Journal of International Economics. 2003. № 27(3-4). Oxford university press. P. 199-220.

[2] Chitaishvili M., Kahcarava L., Center for Social Sciences, 2006 p. 112.

[3] Nelson R. National Innovation Systems: a Comparative Analysis. New York; London: Oxford University Press, 1993. 